\title{
THE PREDICTION OF GROUND LEVEL CONCENTRATIONS
}

\author{
R K Dutkiewicz \\ Professor of Mechanical Engineering, UCT \\ and \\ G P N Venter \\ Head: Air Pollution Research Group, CSIR
}

\section{SINOPSIS}

\begin{abstract}
Vrylatings na die atmosfeer word deur die wind meegedra. Die verspreiding daarvan word beheer deur meganismes soos karakteristieke en die dinamiese toestand van die atmosfeer, wat gekarakteriseer kan word deur die lewensiklus van enige gegewe besoedelstof in die atmosfeer. Verskeie metodes kan aangewend word om die grondvlakkonsentrasie, van 'n besoedelstof vanaf 'n bron soos 'n skoorsteen, te bepaal. Hierdie metodes kan breedweg in twee kategorieë verdeel word, nl. die gebruik van wiskundige modelle vir die beskrywing van die onderliggende prosesse sodat voorspellings gemaak kan word, en tweedens dié waarin van fisiese simuleringstegnieke gebruik gemaak word sodat skaalmetings van die effek van besoedeling op beplande ontwikkelings gemaak kan word in ' $\mathrm{n}$ poging om die impak van besoedeling op die omgewing tot ' $n$ minimum te beperk. Die voorspelling van grondvlakkonsentrasies van besoedeling vanaf skoorstene word binne die raamwerk van die voorafgaande stellings bespreek.
\end{abstract}

\section{SYNOPSIS}

Pollution released into the atmosphere is carried by the mean wind. Its dispersion is controlled by various mechanisms such as source character. istics and the dynamic state of the atmosphere. All these processes manifest themselves in the life cycle of any given pollutant in the atmosphere. Various methods exist for determining the ground level concentration of a pollutant from a source such as a stack. These methods can be divided broadly into those where mathematical models are constructed of the underlying processes so that predictive calculations can be made and into those concerned with the physical simulation of these processes so that scale measurements of the effect of pollution on planned developments can be made to minimize the impact of pollution on the environment. The prediction of ground level concentrations from stacks is discussed within the context of the above statements.

\section{INTRODUCTION}

Even before the introduction of air pollution control legislation in 1965 many industries in South Africa were aware of the environmental implications of effluent released to the atmosphere. A noteworthy example is the town of Sasolburg, which was established and sited with the possible effects of the development of Sasol I and related industries in mind. The exploitation of the mineral resources of the country and the need for the creation of employment opportunities goes hand in hand with continued industrial expansion, especially the chemical, metallurgical, mining and energy sectors.

In order to achieve and to maintain acceptable pollution levels, these developments create a demand for increasingly more efficient control equipment which, in turn, places additional financial burdens in the form of capital outlay and running cost on the industrialist. Because of this and also since no control system is perfect, alternative or complementary ways for achieving acceptable air quality levels must be investigated. One such way is to release the effluent through stacks of sufficient height to disperse it effectively. But what is meant by 'stacks of sufficient height' and when has a given pollutant been 'dispersed effectively'? It is the objectitive of this paper to provide the industrialist with some material to assist him in aswering these questions.

\section{EVALUATION OF THE PROBLEM}

The most reliable way of determining the air pollution situation is measurement either of the pollutant itself or of a satisfactory tracer. Unfortunately such measurements are seldom practical when industrial development and factory or plant design is considered. The only alternative is then to resort to some form of modelling either through the use of predictive methods or by employing physical simulation techniques.

What does the word 'model' imply? A model can be defined as an intellectual construction which attempts to represent reality. To be of practical use, it should be able to predict the consequences of various actions. Obviously, any modelling effort makes a trade-off between simplicity and accuracy.

Two broad kinds of model exist, viz. mathematical and physical models. Both of these attempt to reproduce given real situations. In both the basic conservation laws in physics are used as starting point.

In the case of a mathematical model, realistic assumptions are made about some of the variables in such a way that the resulting equations may be solved explicitly. 
For physical modelling of a problem, the actual situation is approximately reproduced under controlled conditions to such an extent that the different influences of the variables may be studied and measured.

The choice of model and/or technique will depend upon the sophistication of the answer required and on the complexity of the problem. In certain real-life situations the problems may also be such that even the best available methods will only give rough order-of-magnitude answers. For instance, in the case of a source located in complex terrain the following was stated at a specialists' conference on modelling ( 1 ):

'The group was in unanimous agreement that it is not possible to specify a general model for providing a definitive statement concerning the air quality impact of a source or group of sources locating in complex terrain. While a number of generic types and specific algorithms are available, it is not possible to appraise the performance of these models or algorithms .... for one or more of the following reasons

\section{- lack of performance criteria}

- lack of evidence for adequate simulation of physical processes for all possible situations, and

- lack of acceptable evaluation exercises.

... The group made several attempts to develop some guidance material. One suggestion was to enumerate the limitations on the various types of models (Gaussian, $\mathrm{K}$-theory, statistical, etc.) in complex terrain. This approach was abandoned in favour of suggesting ad administrative procedure for use in complex terrain situations ....'.

The main problem of the industrialist is to satisfy the control official that the effluent from his stack will reach the surface in a sufficiently diluted form not to create either a health hazard or to influence the quality of life or, in other words, to be a public nuisance. This is the problem of maximum allowable surface concentration. A secondary problem, of increasing concern in industrialized countries, is the eventual fate of the effluent. A problem in this category is the question of the so-called 'acid rain'. Although this second question is also receiving attention in South Africa, this paper will only address the first one.

\section{LIFE CYCLE OF A POLLUTANT}

As a pollutant is released from a source such as a stack, its behaviour is initially determined by the source characteristics such as initial vertical momentum, temperature of the off-gas, density and source configuration. as it is carried away from the source by the mean wind it follows a certain trajectory which is controlled by the dynamic state of the atmosphere, the buoyancy of the pollutant plume and the underlying topography which may modify the general low level wind field. While being carried by the mean wind the effluent is diluted by turbulence. The concentration of a specific pollutant (such as $\mathrm{SO}_{2}$ ) may also decrease due to chemical transformation to other secondary species (sulphates). The life cycle of a pollutant in the atmosphere is completed by removal through rain-out, washout and dry deposition. In certain cases resuspension may also have to be considered (e.g. particulates).

Generally speaking then, to be able to predict how a pollutant will behave in the atmosphere, models are required for

- release and behaviour close to the source: Plume rise and diffusion

- transport away from the source: Wind field

- dilution while in transit: Diffusion and transformation

- removal: Wet and dry removal

All these aspects can be handled to a greater or lesser degree by relatively simple predictive models or by somewhat more complex numerical computer models. Topographical and physical (building influences, heat sources, diffusion, plume behaviour) aspects can also be handled with relative ease in boundary layer simulation facilities (physical modelling).

As has been implied earlier, in industrial and engineering applications the near-field behaviour is of main concern.

\section{PREDICTIVE MODELS}

Little development in the basic theory of predicting surface concentrations from isolated sources such as stacks has taken place over the past decade. However, the recent exiting developments in boundary layer meteorology should manifest itself in the area of point source diffusion in the near future. For more information on this topic the reader is referred to the review by Hanna (2). Several basic approaches to the problem of diffusion exist in the literature (e.g. Statistical, K-theory, similarity theory) ${ }^{(3)}$, but all of them have weaknesses and all can be applied by appropriate parameterization to give satisfactory results. The choice of approach is however, relatively simple as pointed out by Gifford $(4)$ in the context of diffusion prediction:

'.... The important point is that the Gaussian formula, (statistical theory) properly used, is peerless as a practical diffusion modelling tool: It is mathematically simple and flexible, it is in accord with much though not all of working theory, and it provides a reliable framework for the correlation of field diffusion trials as well as the results of both mathematical and physical diffusion modelling studies'.

The Gaussian formula for a point source of effective height $\mathrm{H}$ and strength $\mathrm{Q}$ is 


$$
\mathrm{C}(x, \mathrm{H}) / \mathrm{Q} \rightleftharpoons \operatorname{xp}\left(-\left(\mathrm{H} / \sqrt{ } 2 \sigma_{\mathrm{z}}\right)^{2}\right) /\left(\pi \sigma_{\mathrm{y}} \sigma_{\mathrm{z}} \mathrm{u}\right)
$$

Where $\mathrm{C}$ represents the plume centreline ground level concentration a distance $x$ from the source; $\sigma_{y}$ and $\sigma_{z}$ describe the spread of the plume in the lateral and vertical directions respectively and $u$ is the mean wind speed along the axis of the plume.

The above form of the Gaussian equation does not take account of the possibility of upper boundaries such as those created by elevated inversions. Hewson and Bierly (Turner $\left.{ }^{(4)}\right)$ studied the problem of plume reflection at boundaries and suggested an expression containing the above parameters and the height of the upper boundary or inversion.

Note that in this paper it is assumed that the effluent is chemically inert and that there is no plume depletion due to deposition. When considering near-field behaviour as is being done here, these are reasonable assumptions. For more details of the theoretical aspects and on chemical reactions various standard textbooks may be consulted e.g. Pasquill(3) and the chapter on turbulent diffusion in a book on industrial meteorology by $\mathrm{Hanna}^{(5)}$.

When equation (1) is applied to the calculation of long term averages and when 16 directional sectors are used, as is the case with standard wind roses, it may be assumed(4) that the directions to which the wind blows in each sector are distributed randomly within that sector, which implies an even distribution in the horizontal, equal to $2 \pi x / 16$ where $x$ is the radial (or down wind) distance from the source. In order to be able to apply equation (1) or its equivalent over long averaging times and with an upper boundary to a problem, information on the following variables is required:

- $\sigma_{\mathrm{y}}, \sigma_{\mathrm{z}}$ as function of stability and down wind distance

- the effective source height

- the frequency $F$, at plume height with which the wind blows in a given direction with a specific stability and mean representative wind speed

- information on the height and frequency of occurrence of the upper boundary (L)

Specification of $\sigma_{\mathrm{y}}(x)$ and $\sigma_{\mathrm{z}}(x)$

The various schemes for determining the $\sigma$-values as function of atmospheric stability are discussed by Gifford(6). For stack sources he states that the scheme of Briggs is probably the soundest for estimating maximum ground level concentrations. Briggs' formulas are reproduced in Table 1.

Venter and Hill ${ }^{(7)}$ have shown that standard methods (such as Briggs' scheme) provide a satisfactory estimation of the sigmas even under very stable conditions. Another form of determining the sigmas is by approximating their distance dependence by power laws of the form $\sigma_{y}=a x P$

$\sigma_{z}=b x^{q}$

TABLE 1. Briggs' formulas for $\sigma_{y}(x)$ and $\sigma_{z}(x)$; $10^{2}<x<10^{4} \mathrm{~m}$, open country conditions

\begin{tabular}{|c|c|c|}
\hline $\begin{array}{l}\text { Pasquill stability } \\
\text { type }\end{array}$ & $\sigma_{y}(x) m$ & $\sigma_{\mathrm{z}}(x) \mathrm{m}$ \\
\hline $\begin{array}{l}\text { A - extremcly } \\
\text { unstable } \\
\text { B - moderately }\end{array}$ & $0,22 x(1+0,0001 x)^{-1 / 2}$ & $0,20 x$ \\
\hline $\begin{array}{c}\text { B - moderately } \\
\text { unstable }\end{array}$ & $0,16 x(1+0,0001 x)^{-1 / 2}$ & $0,12 x$ \\
\hline $\begin{array}{c}\text { C - slightly } \\
\text { unstable } \\
\text { D - neutral }\end{array}$ & $\begin{array}{l}0,11 x(1+0,0001 x)^{-1 / 2} \\
0,08 x(1+0,0001 x)^{-1 / 2}\end{array}$ & $\begin{array}{l}0,08 x(1+0,0002 x)^{-1 / 2} \\
0,06 x(1+0,0015 x)^{-1 / 2}\end{array}$ \\
\hline $\begin{array}{l}\text { E - slightly } \\
\text { stable }\end{array}$ & $0,06 x(1+0,0001 x)^{-1 / 2}$ & $0,03 x(1+0,0003 x)^{-1}$ \\
\hline $\begin{array}{l}\mathrm{F}-\text { moderately }_{\text {stable }} \\
\text { mats }\end{array}$ & $0,04 x(1+0,0001 x)^{-1 / 2}$ & $0,16 x(1+0,0003 x)^{-1}$ \\
\hline
\end{tabular}

In this form the strong role of effective stack height is clearly illustrated as Pasquill(3) points out. He shows that the maximum surface concentration at a pount $x=x_{\mathrm{m}}$, with $\left(\mathrm{H} / \sigma_{\mathrm{z}}\left(\left(x_{m}\right)\right)^{2}=1+\mathrm{p} / \mathrm{q}=\mathrm{j}\right.$, is $\mathrm{C}_{\mathrm{m}} \stackrel{\mathrm{z}}{=} \mathrm{j}^{\mathrm{m} / 2} \exp (-\mathrm{j} / 2) \cdot \mathrm{Q}\left(\sigma^{\mathrm{j}-1} / \sigma_{\mathrm{y}}\right) /\left(\pi u \mathrm{H}^{\mathrm{j}}\right)$ and when $\mathrm{p}>\mathrm{q}$ then $\mathrm{j}>2$. Thus the maximum surface concentration is proportional to something more than the square of the effective stack height $\mathrm{H}$, where the effective stack height is defined as the sum of the source height (physical height of the stack) and the height to which the plume rises above the stack.

\section{Effective stack height}

Venter ${ }^{(8)}$ has shown that two models - the one by Briggs and the other by Moore - predict plume trajectories equally well on the Highveld. Only the model of Briggs will be discussed here in relation to the stability of the atmosphere.

(a) Neutral and unstable lapse rates. According to Briggs (9) buoyancy becomes more important than initial vertical momentum at a distance $x_{1}$ down wind, where

$x_{1}=\mathrm{uw}_{\mathrm{g}} /\left(\mathrm{g}\left(\mathrm{T}_{\mathrm{g}} / \mathrm{T}_{\mathrm{o}}-1\right)\right)$

From the point $x_{1}$ up to the point $x_{2}$, where atmospheric turbulence begins to dominate the rise of a plume, the '2/3-law' holds, where

$\mathrm{H}(x)=1.6 \mathrm{~F}^{1 / 3}-12 / 3$

Here $w_{g}$ is the gas exit velocity in $\mathrm{ms}^{-1}, \mathrm{~T}_{\mathrm{g}}$ is the off-gas temperature, $T_{O}$ is the ambient temperature and $F$ is defined below 
The effect of atmospheric turbulence is to cause a faster rate of mixing of the plume material with its environment. Consequently a downward trend away from the ' $2 / 3$-law' might be expected. However, this has not yet been observed in practice.

Based on an Inertial Range Atmospheric Turbulance Entrainment model - called the 'IRATE' model - Briggs deduced that the plume centre line should gradually level off beyond $x_{2}$. From the point $x_{2}$ onwards he found that the plume trajectory can be described by

$$
\begin{aligned}
& \mathrm{H}(x)=1,6 \mathrm{~F}^{1 / 3} \mathrm{u}^{-1} x_{2}^{2 / 3}\left(2 / 5+16 x / 25 x_{2}\right. \\
& \left.+11 x^{2} / 5 x_{2}^{2}\right)\left(1+4 x / 5 x_{2}\right)^{-2}
\end{aligned}
$$

with $x_{2}$ given by

$$
\begin{aligned}
x_{2} & =14 \mathrm{~F}^{5 / 8} ; \mathrm{F}<55 \mathrm{~m}^{4} \mathrm{~s}^{-3} \\
& =34 \mathrm{~F}^{2 / 5} ; \mathrm{F}>55 \mathrm{~m}^{4} \mathrm{~s}^{-3} .
\end{aligned}
$$

Equation (4) is somewhat cumbersome. Thus, Briggs reasoned that, since the highest ground level concentration normally is found at about $x=5 x_{2}$, i.e. 2,3 times the rise at the transition point, this should be considered the 'final' plume rise. This rise is the same as that given by the ' $2 / 3$ law' with $x=3,5 x_{2}$. Therefore he suggested, as practical procedure, the '2/3-law' up to $x=3,5 x_{2}$ and then a final rise given by

$\mathrm{H}(x)=1,6 \mathrm{~F}^{1 / 3} \mathrm{u}^{-1}\left(3,5 x_{2}\right)^{2 / 3} ; x>3,5 x_{2}$.

The factor $C_{1}=1,6$ is found to be the best fit with experimental data. Briggs gives $C_{1}$ as

$C_{1}=\left(3 / 2 \gamma^{2}\right)^{1 / 3}$

with $\mathrm{r}=\gamma \mathrm{z}$, and $\gamma$ the entrainment constant for buoyant bent-over plumes.

The buoyancy flux $\mathrm{F}$ is given by

$$
\begin{aligned}
\mathrm{F} & =\mathrm{g}\left(1-\mathrm{p}_{\mathrm{g}} / \mathrm{p}_{\mathrm{o}}\right) \mathrm{w}_{\mathrm{g}} \mathrm{r}_{\mathrm{g}}^{2} \\
& \left.=\mathrm{gQ}_{\mathrm{H}} / \pi_{\mathrm{P}} \rho_{\mathrm{o}} \mathrm{T}_{\mathrm{o}}\right) \\
& =3,7 \cdot 10^{-5} \rho_{\text {sea }} \mathrm{QH} / \rho_{\mathrm{o}} .
\end{aligned}
$$

where $\mathrm{p}_{\mathrm{O}}$ is the density of ambient air, $\mathrm{p}_{\mathrm{g}}$ is the effluent density, $r_{g}$ is the stack outlet radius and $Q_{H}$ is the heat emission in $\mathrm{cal} \mathrm{s}^{-1}$.

(b) Stable lapse rates. When a plume rises through stable air it entrains cold air and carries it to warmer regions. Eventually, due to decrease in buoyancy, the plume will cease to rise. The distance at which it reaches its maximum rise is given by Briggs as

$x_{3}=\pi$ us $-\frac{1}{2}$ where $s$ is the stability parameter and $s=\left(g / T_{0}\right) \partial \theta / \partial z$ with $\theta$ the ambient potential temperature.

The maximum rise is given by

$\mathrm{H}(x)=2,9(\mathrm{~F} / \mathrm{us})^{1 / 3}$.

Furthermore, Briggs showed that the '2/3-law' is approximated when

$x=x_{4}>2 \mathrm{us}^{-\frac{1}{2}}$.

Alternatively, for the complete rise up to $x=x_{3}$, Briggs found:

$\mathrm{H}(x)=\left(3 \mathrm{~F} / \gamma^{2} \mathrm{us}\right)^{1 / 3}\left(1-\cos \left(x / \mathrm{us}^{-\frac{1}{2}}\right)\right)^{1 / 3}$

which reduces to equation (10) at $x=x_{3}$ and $\gamma=0,5$

Wind frequency

The function $\mathrm{F}$ as explained earlier should ideally be evaluated over the effective height of influence of the plume. It can also be determined at the surface provided the relationship between surface speeds, directions and stabilities and their upper level counterparts are known or can be determined in some way. The simplest approach is to assume that the surface wind-field can be projected to the height of interest and to couple the various stability categories to the speed and direction intervals into which the statistical information is divided.

\section{Plume trapping}

A stable layer above an unstable layer will have the effect of restricting the vertical diffusion of the plume. At a height of $2,15 \sigma_{z}$ above the plume centreline the concentration will be one tenth of the centreline concentration at the same distance. Thus, when $10 \%$ of the plume centreline concentration extends to the stable layer aloft, it is reasonable to assume that the plume is affected by it. Preston-Whyte et al(10) have shown that a subsidence inversion exists over the Highveld in winter for more than $60 \%$ of the time and that the mean base height above the surface is about $1650 \mathrm{~m}$.

From the foregoing discussion it is evident that for an initial evaluation of the effectiveness of an industrial stack, information on at least the surface wind and temperature fields, elevated inversions and source parameters is required.

\section{CONCLUSIONS}

At the outset it was stated that two questions would be addressed, viz 'what is meant by 'a stack of sufficient height' and when has the effluent been 'dispersed effectively'. From the foregoing paragraphs it is clear that once a 
decision has been reached as to the maximum allowable surface concentration over a given averaging time and with meteorological and process information available, the effective stack height and plume rise can be calculated and hence the stack height can be determined. Of course, the statistical approach (Gaussian formula) is not the only one leading to a solution of the stack problem. There is at present a strong difference of opinion on which road to take - numerical or otherwise - as has been stated in one of the discussion papers on a critical review of dispersion modelling(11) : "It is hoped that the Review will serve in retrospect as the obituary for the overly simplistic Gaussian modelling ..... Then the community can turn to the off-theshelf numerical models' .... Contrasted to this statement the following was also stated: 'Overall, .... this review will serve as an excellent reference document on diffusion modelling'.

The industrialist may also discover that these simple methods cannot solve certain problems, for instance in the problem of determining the influences of large heat emissions from a big industrial area on the performance of a stack. Then recourse has to be taken to simulation methods such as those of Dutkiewicz and Fuggle(12), where they successfully modelled the diffusion of effluent in the complex meteorological and topographical setting of the Cape
Peninsula.

\section{REFERENCES}

1. REPORT TO US EPA OF THE SPECIALISTS' CON FERENCE ON THE EPA MODELLING GUIDELINE, Feb 1977, Chicago, 111. Organized by: Energy and Environmental Systems Division, Agonne National Lab., sponsored by the Office of Air Quality Planning and Standards, US EPA.

2. HANNA, S.R. (1978). A review of the influence of new boundary layer results on diffusion prediction techniques. Paper presented at the WHO Symposium on Boundary Layer Physics applied to specific problems of air pollution, Nörrkoping, 19-23 June 1978.

3. PASQUILL, F. (1974). Atmospheric Diffusion, John Wiley and Sons, London.
4. TURNER, D.B. (1970). Workbook of Atmospheric Dispersion Estimates. EPA, Office of Air Programs, Research Triangle Park, North Carolina, USA.

5. HANNA, S.R. (1979). Chapter 10: Chimneys and Cooling Towers to be published in the book Industrial Meteorology, E. Plate, ed. Ref. ERL, Air Resources Atmospheric Turbulence and Diffusion Laboratory, Oak Ridge, Tennesee, Dec. 1979, 1978 Annual Report ATDL - 79/16. US Dept. of Commerce.

6. GIFFORD, F.A. (1976). Turbulent diffusion - typing schemes : A Review, Nuclear Safety, Vol. 17(1), $25-43$.

7. VENTER, G.P.N. and HILL, D. (1976). The prediction of pollutants released into a dynamically very stable atmosphere. Paper presented at the International Conference on Air Pollution, Univ. of Pretoria, March 1976.

8. VENTER, G.P.N. (1977). A comparison of observed plume trajectories with those predicted by two models. Atmos. Environ., 11, 421-426.

9. BRIGGS, G.A. (1970). Some recent analyses of plume rise observations. 2nd Int. Clean Air Congress, 1029-1032, IUAPPA, 6-11 Dec., Washington, D.C.

10. PRESTON-WHYTE, R.A. et al (1977). Towards an inversion climatology of Southern Africa: Part II, Non-surface inversions in the lower atmosphere, $S A$ Geogr.j., 59(1), pp. 45-59.

11. Atmospheric Dispersion Modelling: A Critical Review - Discussion papers, Journ. APCA, Sept 1979, Vol. 29(9), 927-941.

12. DUTKIEWICZ, R.K. and FUGGLE, R.F. (1977) Diffusion in a complex topography - a comparison of wind tunnel and ambient measurements. Proc. 4th Int. Clean Air Congress, Tokyo, Japan, May
16-20,188-191. 